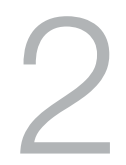

\title{
Allies of a kind: Three wartime Australian ministers to the United States, 1940-46
}

\section{Carl Bridge}

Australia's first legation in Washington was born amid the gathering storm clouds of World War II, conceived under Prime Minister Joseph Lyons and announced under his successor Robert Menzies. During the war, three ministers served as head of mission: Richard Casey (1940-42); Sir Owen Dixon (1942-44); and Sir Frederic Eggleston (1944-46). Each was appointed a minister in charge of a legation - a rank and mission below that of ambassador and embassy, so as not to break the formal diplomatic unity of the British Empire/ Commonwealth. Menzies' intention was that the minister would act in tandem with the British Ambassador (formally in the senior imperial post) and embassy to achieve common, if independent, goals. ${ }^{1}$ Of course, this proved almost impossible in practice in a global war with multiple enemies and fronts and finite resources. Unity of a kind was preserved, but the devil was in the details.

1 Menzies' instructions to Casey are in Casey to Roosevelt, 5 May 1940, letter, series RG59, item 701.4711/76 United States National Archives (USNA), College Park, Washington DC. 


\section{False starts: 1907 to 1939}

The prehistory of Australian diplomatic representation to and in the US stretches back to 1907, and the story is one of a succession of false starts until Casey's appointment in late 1939. ${ }^{2}$ Alfred Deakin's invitation in 1907 to the US Government to include Sydney and Melbourne as ports of call on the world cruise of their 'Great White Fleet' of 16 battleships was Australia's first official invitation to the Americans. The visit in August 1908 was a huge success but the fleet sailed away again leaving no lasting legacy; though it did help set the scene for Deakin's establishing of the Royal Australian Navy soon afterwards. ${ }^{3}$ Many Australians were unimpressed by US neutrality during most of the Great War and by their refusal subsequently to join the new League of Nations. Prime Minister William Morris (Billy) Hughes, following a visit to the US and a meeting with President Woodrow Wilson, appointed a Trade Commissioner in New York in 1918, mostly for purposes of war procurement, and the office lasted just over a decade until it was snuffed out by the Depression; partly because, as one Australian Cabinet Minister, Sir Henry Gullett, complained, it 'encouraged bigger Australian purchases in America, than American purchases in Australia' (though it was quietly re-established in 1938). ${ }^{4}$ When asked in 1927 why Australia had not followed Canada, South Africa and Ireland in appointing a diplomat to Washington, Prime Minister Stanley Melbourne Bruce replied loftily: 'Such appointments - when there is no close relationship between the countries or special questions to be dealt with - were mere indications of an inferiority complex. ${ }^{5}$ As Gullett foreshadowed, trade was a major bone of contention, with the US running a four-to-one balance of trade surplus with Australia throughout this period. This was the cause of a unilateral,

2 See my 'Relations with the United States' in Carl Bridge and Bernard Attard (eds), Between Empire and Nation, Australian Scholarly Publishing, Melbourne, 2000, ch. 5; Ruth Megaw, 'Undiplomatic Channels: Australian Representation in the United States, 1918-39', Historical Studies, vol. 15, no. 60, 1973, pp. 610-30; Norman Harper, A Great and Powerful Friend: A Study of Australian-American Relations Between 1900-1975, University of Queensland Press, Brisbane, 1987; and Raymond A Esthus, From Enmity to Alliance: U.S.-Australia Relations 1931-41, Melbourne University Press, Melbourne, 1964.

3 Still the best authority here is Neville Meaney, The Search for Security in the Pacific, 1901-14, Sydney University Press, Sydney, 1976. But see also Russell Parkin and David Lee, Great White Fleet to Coral Sea, Department of Foreign Affairs and Trade, Canberra, 2008.

4 Gullett was reported by Jay Pierrepont Moffat, US Consul-General in Sydney: Moffat Diaries, 1 June 1936, Houghton Library, Harvard University, Cambridge, Massachusetts, USA.

5 Cited by Megaw, 'Undiplomatic Channels', p. 618. 
short-lived and ill-fated attempt by Australia at 'Trade Diversion' away from the US and Japan and in favour of Britain in 1936-37. When the British negotiated the Anglo-American Trade Treaty of 1938, partly at Australia's expense and mostly for security reasons, Australia remained aloof. ${ }^{6}$

It was, however, the quest for security that finally caused a rethink in Canberra. In May 1937, following personal encouragement from President Franklin Roosevelt, Lyons appointed the Australian diplomat Keith Officer to a middle-ranking position as counsellor in the British embassy in Washington with a brief to report rather than act. ${ }^{7}$ Officer did not have direct access to the US Secretary of State, let alone the President. The limitations of this arrangement were soon exposed. After the Marco Polo Bridge incident in July 1937 escalated Japan's war in China and the Munich and Prague crises of 1938 and 1939 respectively brought Britain and France to the brink of war with Germany, it was decided that full diplomatic missions should be set up in Washington, Chungking and Tokyo. The time for mere listening was over.

Willy-nilly, the era of direct Australian diplomacy in the AsiaPacific had arrived, and arguably somewhat ahead of the bureaucracy supporting it. The three ministers under examination here reported to a young Department of External Affairs (made a separate administrative department in 1935) in Canberra that was finding its way among other, more established departments with remits for overseas relations, such as Trade and Defence, and a Prime Minister's Department to which Australia's High Commissioner in London reported directly. World War II would see the Department of External Affairs grow in personnel, just as Canberra itself grew in bureaucratic size and accumulating centralised powers, as the government responded to the exigencies of war. The Secretary of External Affairs from 1935 to 1944 was the tough but unadventurous former military man, Colonel William Roy Hodgson. From October 1941, Australia's Minister for External Affairs was Dr Herbert Vere Evatt, an intellectually restless, always demanding and partisan-Labor minister who was determined to gather around him the brightest officials who could be recruited. To this end he instigated

6 Ruth Megaw, 'Australia and the Anglo-American Trade Agreement, 1938', Journal of Imperial and Commonwealth History, vol. 3, no. 2, 1975, pp. 191-211.

7 Alan Fewster, Trusty and Well Beloved: a Life of Keith Officer, Miegunyah Press, Melbourne, 2009. 
a diplomatic cadetship scheme from 1943, but Australian representation in Washington was in the hands of political appointees and, until later in the decade, the reception of those representatives' views was also largely in the hands of politicians such as Evatt and Prime Ministers Curtin and then Chifley.

\section{Casey: February 1940 to February 1942}

At 50 years old, Casey was the youngest of the three wartime ministers to the US. Lyons' former Treasurer and Bruce's former Liaison Officer in the British Cabinet Secretariat in London in the 1920s, he was admirably suited for the job of establishing the legation - well-connected, politically experienced, a man of great independent wealth, trained as an engineer, with a distinguished war record, and dedicated to public service. ${ }^{8}$ He began with two other diplomatic staff and ended with six.

When Casey presented his credentials to Roosevelt, the US leader told him that in its relations with Australia 'the element of distance denoted a declining interest on the part of the United States'. ${ }^{9}$ The clear message was that Britain and its empire should look to their own defence. Attempting to reverse this situation became the principal objective of Casey's mission. In order to achieve this, Casey decided upon a twopronged strategy: a propaganda campaign across the US to publicise Australia and its war effort; and a succession of formal diplomatic initiatives aimed at persuading the American Administration of its need to join the war. A third, related aim was to win the confidence of the American military leadership.

First, let us examine propaganda, or strictly speaking information, because in the US at that time war propaganda was illegal. This was isolationist America, shielded behind Neutrality Acts. A contemporary Sydney Bulletin cartoon by Norman Lindsay captioned 'Darkest America', and to modern readers blatantly racist, showed Casey in an explorer's pith helmet as a sort of Stanley in the deep jungle meeting a Livingstone figure. This man was a rather Germanic-looking American

8 On Casey's background, see William James Hudson, Casey, Oxford University Press, Melbourne, 1986; and Casey's own memoirs: Personal Experience, 1939-46, Constable, London, 1962, and Australian Father and Son, Collins, London, 1966.

9 Casey to Sir Henry Gullett, Minister for External Affairs, 9 March 1940, letter, in Carl Bridge, (ed.), A Delicate Mission: The Washington Diaries of R.G. Casey, 1940-42, National Library of Australia, Canberra, 2008, p. 30. 
with a book under his arm labelled 'Isolation' and a file of black carriers behind him. The caption read 'Dr Livingalone, I presume?' ${ }^{10}$ Ian Clunies Ross, an Australian who was Head of the International Wool Secretariat, advised Casey through Menzies to hire a firm of New Yorkbased public relations consultants, Earl Newsom and Company, to set up a campaign. One can market 'Australia' to the Americans just as one can market 'wool' or 'tea', Clunies Ross wrote. ${ }^{11}$ And he was not far wrong.

Casey's family was photogenic. He was conventionally handsome with a clipped military moustache. A dapper dresser, he had a marked resemblance to the pin-up boy of British politics, Sir Anthony Eden, a sort of political George Clooney of the day, and was soon labelled by the American press 'The Anthony Eden of Australia'. He and his wife, Maie, who was a notable artist, designer and art collector, flew their own small aeroplane, and journalists were quick to dub the pair 'The Flying Caseys'. In two years Casey made 70 major speeches in key venues across the country, 16 of them broadcast on radio, three of these coast-to-coast, and all extensively reported in the press. There were also publicity stunts galore, from his teaching Vice-President Henry A Wallace to throw a boomerang and acquiring Australian animals for American zoos to his unsuccessful attempt to get Walt Disney to introduce Australian cartoon characters, a kangaroo and a koala. Maie organised a major touring exhibition of Australian art through the Carnegie Foundation and wore gowns of fine Australian wool. ${ }^{12}$ The Caseys dined, entertained and networked prodigiously in their residence-cum-mission, a colonial revival mansion purchased by the Australian Government on their advice. 'White Oaks', with its red bricks, white columns and portico, was built by a speculator in 1928, sat in leafy and dignified Cleveland Avenue (number 3120), and had once been rented by General George S Patton. ${ }^{13}$

10 Bulletin, Sydney, 17 January 1940.

11 Menzies to Casey, 19 March 1940, cablegram, series A3300/66, National Archives of Australia (NAA), Canberra.

12 On Maie's role, see Maie Casey, Tides and Eddies, Joseph, London, 1966; Diane Langmore, Glittering Surfaces: A Life of Maie Casey, Allen \& Unwin, Sydney, 1997; and Audrey Tate, Fair Comment: A Life of Pat Jarrett, 1911-1990, Melbourne University Press, Melbourne, 1996. Jarrett was Maie's secretary.

13 This aspect is discussed in detail in my 'Introduction' to A Delicate Mission, pp. 5-9, and in Bridget Griffen-Foley, “The Kangaroo is coming into its own”: R.G. Casey, Earl Newsom and Public Relations in the 1940s', Australasian Journal of American Studies, vol. 23, no. 2, 2004, pp. 1-20. 
The propaganda blitz worked well. Casey put himself and Australia on the US map. So successful was it that when Sir Keith Murdoch, in his wartime post as Australia's Director-General of Information, wanted to crank it up even further in August 1940 with a grandiose campaign of paid advertisements in the press, the State Department advised Casey that they thought it would be counterproductive and stir up criticism from the isolationist lobby. More important, they thought, rightly, that his other activities were sufficiently effective. In his speeches, Casey presented Australia as defending democracy in a threatened world, in effect underwriting US freedom. Australia in the Pacific was depicted as a new country, and Australians were egalitarian, easygoing, freewheeling and get-up-and-go, like their American cousins: potentially a Pacific partner, as Australian war correspondent and author George Johnston put it in an ex post facto book published in 1944. ${ }^{14}$ The British Empire was fighting Fascist Germany and Italy alone and could do with American help. ${ }^{15}$ Privately, in his diary, Casey despaired. While the Battle of Britain raged and France fell, Americans were around him enjoying the sun on holiday in Florida or on the beach at Atlantic City. The British element of the US population, he wrote, was too diluted for them to realise the 'Old Country' needed help. ${ }^{16}$

On the formal diplomatic front, working, as Casey put it, as the 'other blade of the scissors' to Lord Lothian (and later Lord Halifax), the British ambassadors, Casey saw the President regularly - often with the British Ambassador but 11 times on a one-to-one basis. He also met often with the Secretary of State, Cordell Hull, General George Marshall, the military chief, and many others at the top of American politics and administration. He had a good working relationship with Harry Hopkins, Roosevelt's principal aide, and made close friends of Felix Frankfurter, the Supreme Court judge, and Dean Acheson, a senior diplomat. The prominent journalists and columnists Walter Lippmann, George Fielding Eliot and Dorothy Thompson were regular contacts.

There is not space here to tell the detailed story, but Casey, Lothian and Halifax hardly missed a trick. They placed stories in the press about how the Royal Navy guaranteed the US' Monroe Doctrine, which kept

14 George H Johnston, Pacific Partner, Victor Gollancz, New York, 1944.

15 For example, his speech to the National Press Club, Washington, 12 March 1940; and his broadcast address on the Columbia Broadcasting Service, 22 March 1941, series A981/Australia 221, NAA, Canberra.

16 See, for example, his diary entries for 5 June and 13 July 1940, A Delicate Mission. 
foreign powers from meddling in the Western Hemisphere; Casey even tried cheekily to insinuate text to this effect into Roosevelt's speeches (March-July 1940). They helped engineer the temporary closure of the Burma Road supply route from India into China (July-September 1940) both to appease the Japanese and at the same time demonstrate the need for US support when the road was reopened. They helped hatch the 'Destroyers-for-Bases' deal (September 1940) and the secret ABC1 strategic talks between the British and US militaries nearly a year before Pearl Harbor, at which an Australian naval observer, Commander Henry Burrell, was present (January-March 1941). They encouraged the passage through Congress of the historic Lend-Lease Act, revolutionising the financing of the British war effort (March 1941), and they were complicit in the drafting of the Atlantic Charter (August 1941). And Casey was careful to inject Australian and Pacific dimensions as he went, for instance by successfully offering the US Army Air Corps the use of Darwin as a southern staging post en route to the Philippines well in advance of Pearl Harbor. All of these were way stations on the road to US full participation in the war. ${ }^{17}$

But it was not propaganda and diplomatic moves that brought the US into the war. It was the march of international events, which showed that the American economy was so dependent on its trade with Britain and the empire, and equally dependent on the empire's fighting that compelled the US to join in. In particular, the German U-Boats' depredations against US's transatlantic trade and increasing German autarky on the European continent began to squeeze the American economy, still fragile in its recovery from the Great Depression, making the US increasingly more dependent on trade with Britain and its empire. ${ }^{18}$ Events and the economic pressures of war convinced Japan to act, too, and its attack on Pearl Harbor on 7 December 1941 finally achieved Casey's and Halifax's objective for them. ${ }^{19}$

17 For more detail, see my 'Introduction', A Delicate Mission, pp. 9-11. For the British perspective on these developments, see David Reynolds, The Creation of the Anglo-American Alliance, Europa, London, 1981.

18 Roosevelt pointed out in the 1940 Presidential Election campaign that the war had boosted the 'neutral' US economy by 3.5 million jobs and was a major factor in pulling the country out of the Depression: David M. Kennedy, Freedom from Fear: The American People in Depression and War, 1929-1945, Oxford University Press, New York, 1999, p. 464.

19 Kennedy, Freedom from Fear; Warren F. Kimball, The Juggler: Franklin Roosevelt as Wartime Statesman, Princeton University Press, Princeton, 1994; and The Most Unsordid Act: Lend-Lease 1939-41, Princeton University Press, Princeton, 1991. 
That great sceptic, Stanley Melbourne Bruce, at the time sitting as Australian High Commissioner in London, pronounced Casey's achievement across the pond to be 'a star performance', ${ }^{20}$ and another with an even better ringside seat, Casey's First Secretary at the legation, Alan Watt, would write in his memoirs:

It has always been my view that Casey's work in Washington and the United States generally has been under-estimated in his own country. It was not easy in advance of Pearl Harbor, to develop a favourable climate of opinion towards Australia. This the Australian Minister undoubtedly did. ${ }^{21}$

The extremely partisan Herbert Evatt, the new Labor Foreign Minister at the time of Pearl Harbor, said privately to a New Zealand counterpart that Australia had 'a swine in Washington named Casey'. ${ }^{22}$ It was an awareness of Evatt's hostility, coupled with his sense that his main task had been completed, that persuaded Casey to resign from his post in early 1942, whereupon a grateful Winston Churchill made Casey British Cabinet Minister Resident in the Middle East, based in Cairo. It was another crucial posting for Australia, given that Rommel's Afrika Korps was threatening the main Suez Canal supply route to Australia, and the Australian 9th Division and air and naval elements were serving in that theatre. Despite Evatt's doubts, however, John Curtin, Australia's new Labor Prime Minister, made it quite clear that he would have rather kept Casey in Washington. ${ }^{23}$

\section{Sir Owen Dixon: June 1942 to September 1944}

Perhaps in a conscious effort to counter Evatt, Curtin went to the High Court to find Casey's successor. Sir Owen Dixon, aged 56, was at the height of a stellar legal career, and as wartime tasks had been chairing the boards overseeing Australia's shipping, wool and stevedoring interests. An internationally pre-eminent black-letter lawyer, and a man who took

20 Bruce to Casey, 17 September 1941, letter, cited in Hudson, Casey, p. 122.

21 Alan Watt, Australian Diplomat: Memoirs of Sir Alan Watt, Angus and Robertson in association with the Australian Institute of International Affairs, Sydney, 1972, p. 35.

22 Nelson T Johnson, United States Minister to Australia, to Cordell Hull, Secretary of State, 23 April 1942, in Peter Geoffrey Edwards (ed.), Australia through American Eyes, 1935-1945, University of Queensland Press, Brisbane, 1979, p. 69.

23 Bridge, 'Introduction', A Delicate Mission, pp. 11-13. 
infinite pains to achieve complex tasks, Dixon was an ideal choice for the Washington post at this stage of the war. Nevertheless, he was reluctant to go, not wanting to be labelled an 'evacuee' like Evatt, and it was only after considerable pressure from Curtin that he accepted the post as a war task. ${ }^{24}$

With terrier-like but always polite determination, Dixon would ensure the best possible supplies for Australia of aircraft and other war materials. 'How to divide a deficiency is always the question?', he wrote in defining the key business of his mission. ${ }^{25} \mathrm{He}$ handled with consummate skill the fiendish intricacies of Lend-Lease and Reciprocal Lend-Lease. (Like Thomas Gradgrind, Dixon wanted 'facts, facts, facts' and was averse to and avoided political and bureaucratic spin. ${ }^{26} \mathrm{He}$ also firmly and persistently, though unsuccessfully, questioned the 'Beat Hitler First' grand strategy of the Allies, in the Australian Government's interest. On one notable occasion at a meeting of the Pacific War Council in March 1943, Roosevelt instructed Dixon on the basics of grand strategy. The President said colloquially but pointedly: 'The situation was not to be defeated by Hitler before we dealt with the Japs.' And Roosevelt was correct: geopolitical analysis shows that Germany, with over four times the war-making capacity of Japan, had to be first priority, or the Allies would lose the war. ${ }^{27}$ Earlier, at the time of Kokoda (July-September 1942), an annoyed Roosevelt had cabled Curtin, through Dixon, refusing him reinforcements on the grounds that after the Battle of Midway the Japanese no longer had the capacity to invade Australia and were fully occupied in the Guadalcanal battles. ${ }^{28}$

It also fell to Dixon to report and help shape the early steps in 1943 towards a new international organisation, via the new United Nations Relief and Rehabilitation Administration. Personally wary of Evatt whom he knew only too well having sat with him on the High Court bench for 10 years - Dixon had himself appointed as answerable directly

24 Dixon on Evatt, cited in Philip Ayres, Owen Dixon, Miegunyah Press, Melbourne, 2007, p. 134; Watt, Australian Diplomat, p. 52.

25 Dixon to Sir Frederic Eggleston, Australian Minister to China, letter, 13 July 1942, William James Hudson and Henry James William Stokes (eds), Documents on Australian Foreign Policy 19371949 (DAFP), vol. VI, July 1942 - December 1943, Australian Government Publishing Service, Canberra, 1983, doc. 6 .

26 Watt, Australian Diplomat, p. 53.

27 Dixon's diary, 31 March 1943, cited in Ayers, Dixon, p. 163; Paul Kennedy, The Rise and Fall of the Great Powers: Economic Change and Military Conflict from 1500-2000, Unwin Hyman, London, 1988, p. 430.

28 Dixon to Curtin, 16 September 1942, cable, $D A F P$, vol. 6, doc. 48. 
to the Prime Minister, though this arrangement never quite worked. Dixon first tried to resign in May 1943 while on a mid-term visit to Australia; this was due in no little degree to his fallings out with Evatt, but he was persuaded by Curtin to stay on ad interim. Meeting the Curtin War Cabinet during the visit, a disillusioned Dixon confided later to a friend that he found them a 'pusillanimous crew'. ${ }^{29}$ Dixon finally returned home in September 1944.

As minister in Washington, Dixon had some difficult hands to play. When the fighting was at its worst on the Kokoda Track, he had to reassure Roosevelt and Marshall that the matter was in hand, despite stories of Australian troops fleeing before the enemy, as some had done earlier that year from the bombing of Darwin. He had to explain why Australia would not send military conscripts into New Guinea but would allow US conscripts to do the job. ${ }^{30} \mathrm{He}$ had to try to explain the controversial Anzac Pact of January 1944, an act of Evattean bombast in which Australia and New Zealand claimed primacy in the South West Pacific over the US, when the US Administration had a copy of the text of the agreement and he did not. ('Let's just forget it [the Pact]' was Roosevelt's dismissive response to the hapless Dixon.) $)^{31}$ And he had to explain why Australia was apparently beginning to demobilise its forces in the latter part of 1943 when the US was still fighting full tilt. ${ }^{32}$

All of this Dixon did as effectively as anyone could have done, but it was a less rewarding task than Casey's. Dixon did, however, have two major weaknesses as a diplomat. As a man drilled in the legal profession, he preferred to work alone and master his brief, with one legal assistant to devil for him, Keith Aickin, who was seconded from the court to Washington as Third Secretary. Dixon did not utilise his diplomatic staff as efficiently as he might have done and this infuriated First and Second Secretaries Alan Watt and Peter Heydon. ${ }^{33}$ Dixon was also happier with administrators, technicians and the military than he was with politicians. Though he won Marshall's confidence and that of the LendLease people, he did not read the runes of the general political situation

29 Paul Hasluck, Diplomatic Witness: Australian Foreign Affairs, 1941-1947, Melbourne University Press, Melbourne, 1980, p. 44.

30 Dixon's diary, 12 June, 1, 7 and 8 October 1942, cited in Ayers, Dixon, pp. 145, 154-55.

31 Ayers, Dixon, p. 173. On the Anzac Pact, see Robin Kay (ed.), The Australian-New Zealand Agreement 1944, Historical Publications Branch, Wellington, 1972; and Anthony Burke, Fear of Security: Australia's Invasion Anxiety, Cambridge University Press, Melbourne, 2008, p. 78.

32 Dixon's diary, 10 April 1944, cited in Ayers, Dixon, p. 172.

33 Watt, Australian Diplomat, p. 52; Ayers, Dixon, pp. 142, 147. 
and report on trends in, for instance, Roosevelt's re-election campaign in $1944 .{ }^{34}$ Nor was he close enough to Roosevelt or Halifax to divine the thinking of the 'Big Three' (Roosevelt, Churchill and Stalin) at the Casablanca (January 1943), Quebec (August 1943), Tehran and Cairo (November-December 1943) summits. (Halifax refused to tell him fully about Casablanca and he first learned the outcome of Quebec from the Australian High Commission in Ottawa.) ${ }^{35}$ One cannot imagine Casey allowing himself to get so out of touch with the high political game.

Dixon, like Casey, had to attempt to make up for Evatt's failings; for example, on one occasion Evatt criticised the British for their 'selfishness' in a meeting with General Marshall, who stood up and pointed out that he would not hear such disloyalty to his country's 'most important ally' ${ }^{16}$ There would have been no need for an Anzac Pact had Evatt and Dixon won more inside influence in Washington. As historian John Robertson described it, from 1944 Australia slipped into the role of 'redundant ally'. ${ }^{37}$ This happened on Dixon's watch.

In the end, soon after the great D-Day assault in Normandy in June 1944, and while in the Pacific the assault on the Philippines was brewing, Dixon was happy to go back to Australia and the High Court. His American friends praised him for his intelligence, balance and disinterestedness. One might wonder, however, whether these virtues suffice in the world of a diplomat.

\section{Sir Frederic Eggleston: November 1944 to April 1946}

In September 1944, when he was offered the post as minister in Washington, Sir Frederic Eggleston was 69 years old, very overweight, and suffering from chronic gout, neurasthenia and arthritis. He had been minister to China for four years, based in Chungking, during which time he had had to be carried about that hilly city in a perambulator

\footnotetext{
34 This political blind spot and his tendency to equanimity in discussions with the Americans are what Watt was referring to when he wrote to a friend of Dixon being 'not only out of place, but possibly doing Australia unintentionally considerable disservice'. Watt to JD Hood, 7 September 1943, Sir Alan Watt Papers, series MS3788, National Library of Australia, Canberra.

35 Ayers, Dixon, pp. 159, 170.

36 Watt, Australian Diplomat, p. 52.

37 John Robertson, Australia at War, 1939-1945, Heinemann, Melbourne, 1981, ch. 18.
} 
(a sort of open sedan chair) by his Chinese staff. Eggleston had a formidable intellect, had been at Versailles for the peace negotiations in 1919, had had a stint as a Victorian Liberal state politician and minister, and had chaired the Commonwealth Grants Commission successfully throughout the 1930s. He had an intense theoretical and practical interest in international organisation and relished going to Washington to participate in the making of the next equivalent of the Treaty of Versailles and the framing of what became the United Nations Organization. ${ }^{38}$

Eggleston wrote to Evatt that he feared his health would not bear the strain but 'if the Government was willing to take the risk I am'. ${ }^{39}$ $\mathrm{He}$ anticipated he would last about six months. 'The Egg', as the diplomatic cadets he instructed in the late 1940s would call him, in the words of another senior diplomat Sir Walter Crocker, 'enjoyed thinking as some men enjoy drinking. ${ }^{40}$

Unfortunately, as Watt sourly noted, Eggleston's immobility was a great hindrance in Washington. The senior Americans did not have the time to call on him and he had only limited energy to call on them. His junior staff could not fully compensate for this as inevitably they only got to see other juniors. ${ }^{41}$ At the San Francisco Conference in AprilMay 1945, where Eggleston should have been in his element, he broke down and was hospitalised for a week, and convalescing, was taken on long, therapeutic car rides by Leslie Finlay (Fin) Crisp, a junior member of the Australian delegation. ${ }^{42}$ Evatt, who was de facto head of the Australian team there, preferred to use his own personal staff, principally Paul Hasluck, and did not talk to or use Eggleston. As Hasluck observed in his memoirs, Eggleston was 'left behind in the rush', his carefully written analyses of issues too late to be useful and left unread. ${ }^{43}$

38 Warren G. Osmond, Frederic Eggleston: An Intellectual in Australian Politics, Allen \& Unwin, Sydney, 1985, is an excellent biography.

39 Eggleston to Evatt, 27 September 1944, letter, in William James Hudson (ed.), DAFP 1944, vol. 7, Department of Foreign Affairs and Trade, Canberra, 1988, doc. 303.

40 Sir Walter Crocker cited in Osmond, Eggleston, p. 301.

41 Watt, Australian Diplomat, pp. 60-1.

42 Osmond, Eggleston, p. 248.

43 Hasluck, Diplomatic Witness, p. 191. See also: Watt, Australian Diplomat, p. 67. Watt, who was with the Australian delegation, thought it 'undignified' for Eggleston to remain at San Francisco and thought he should have returned to Washington and his work as head of mission. 
Nevertheless, Eggleston did play something of a role, justifying Australia's positions, particularly on trusteeship matters in arguments with Halifax and the British delegation, and over elected membership of the projected UN Security Council. Eggleston has left us with an eloquent analytical summation of Evatt's achievement at San Francisco in a letter to Bruce, still High Commissioner in London:

As a matter of fact I consider that Evatt performed a great intellectual tour de force at San Francisco ... I know all of Evatt's weaknesses and have no admiration for the way in which he works but I have to confess that I believe he played a very constructive part at the conference and that he pointed out the weak points of the main scheme, conducted a fine campaign against them, and that on the question of the Economic and Social Council and the Trusteeship clause, he was very largely responsible for the draft which appeared ... You must not take it that Evatt's campaign was merely a small power v[ersus] a great power campaign. It was a campaign against the defective principles of the Charter. ${ }^{44}$

Wars, Eggleston told a meeting of the British delegation when discussing the need for elected members in the Security Council, were caused by great powers, not small ones, and that great power virtue was no guarantee against them. ${ }^{45}$ Halifax, whose 'Holy Fox' nickname was welldeserved, refrained from pointing out the obvious to the sanctimonious Eggleston, which was that small power virtue mattered even less.

In 1947, Eggleston wrote a letter to a friend wherein he perceptively identified his own strengths and weaknesses:

I do not care whether I am at the head of the procession. Where the ego should be I form a sense of humour, and the reason why I like being at the tail ... is that I can tell people's character better from their walk and the backs of their heads than their faces, which are of course synthetic. ${ }^{46}$

Eggleston was by temperament an observer and commentator rather than an actor, and, as his acute biographer Warren Osmond remarks, this made him ultimately 'unsuitable for positions of power'. ${ }^{47}$

44 Eggleston to Bruce, 9 July 1945, letter, in William James Hudson and Wendy Way (eds), DAFP 1945, vol. VIII, Department of Foreign Affairs and Trade, Canberra, 1989, doc. 130.

45 Ibid.

46 Eggleston to Mrs Katrine Ball, 8 September 1947, letter, cited in Osmond, Eggleston, p. 252.

47 Osmond, Eggleston, p. 252. 
Eggleston increasingly found himself out of sympathy with the Americans, and in September 1945, soon after the Peace, wrote to his nephew:

I am getting rather fed up with the American atmosphere. The Americans are slow to action, dashing when in fight, and intolerable in victory. I have never seen such National Egotism as this outburst. Whether they will get through the reconversion [to peace] I don't know, but all controls are being discontinued. From now until Christmas they will hog themselves into their food while Europe is starving. ${ }^{48}$

While the San Francisco Conference and Japanese Peace Treaty talks diverted him for another six months, he was more than glad in April 1946 to return to Australia 'to sit on a verandah and play with my grandchild'. ${ }^{49}$

\section{Allies of a kind}

Three very different Melburnians served Australia to the best of their considerable abilities in Washington during World War II. It was never easy representing a junior ally to the great power leadership in a global war; and even harder trying to involve a great power in a war they were reluctant to enter. If, as the historian Christopher Thorne put it so well, the US and the UK were 'Allies of a Kind', drawn together for a common purpose but with all sorts of contradictory tensions straining below the surface, Australia, dependent on both and with only a limited amount to offer in return, had an even more difficult row to hoe as a dual ally of an even more qualified kind. ${ }^{50}$ Casey, the politician, endured the agony of witnessing American neutrality during the fall of France and the Battle of Britain and helped prepare the American people and their administration to join in the war - a process completed by the Japanese attack on Pearl Harbor. Dixon, the luminous High Court judge, handled the complexities of supply for Australia's part of the Pacific War with great skill, but failed in the high political task of discovering and reporting the evolving political and military strategies of the Big Three.

48 Cited in Osmond, Eggleston, p. 248.

49 Ibid., p. 249.

50 Christopher Thorne, Allies of a Kind: the United States, Britain and the War Against Japan, 1941-1945, Hamilton, London, 1979. 
Eggleston, the partial invalid and intellectual, was a thoughtful analyst of the crucial events at the San Francisco Conference, but too ill to make a significant contribution to proceedings as they happened. Only Casey possessed all of the necessary skills and the will to successfully execute all aspects of this demanding position. The other two had significant gaps. Casey, the vitally interested politician-cum-diplomat, was best suited to the role and performed the most important task. 
This text is taken from Australia goes to Washington: 75 years of Australian representation in the United States, edited by David Lowe, David Lee and Carl Bridge, published 2016 by ANU Press, The Australian National University, Canberra, Australia. 